\title{
ARBITRASE ISLAM DALAM PERSPEKTIF ISLAM DAN HUKUM POSITIF
}

\author{
The Islam Arbitration in Islam Perspective and Positive Law
}

\author{
Tri Setiady \\ Fakultas Hukum, Universitas Wiralodra \\ email: trisetiady@yahoo.com
}

\begin{abstract}
The business world today has grown indefinitely so as to break through the dimensions of human life and behavior of the economy into banking minded and change the values and aspects of the business itself, either legally or sociologically. Business development with the pattern and any system can not be separated from the financial institution whose name the bank. Banking deregulation undertaken by the government has been precise to support the economy in order to develop better. With the enactment of Law Number 10 of 1998 concerning amendments to the Law Number 7 of 1992 on Banking, is an opportunity and provide an opportunity for Muslims to establish a bank based on Islamic Shari'a, as support to the business world and the economy of the people. With the presence of banks based on Islamic Shari'a is expected to accelerate the economic revival in the race entering the era of globalization.
\end{abstract}

Keywords: Arbitration of Islam, the Islamic Perspective, Positive Law

\begin{abstract}
abstrak
Dunia bisnis saat ini telah berkembang tanpa batas sehingga mampu menerobos dimensi kehidupan dan perilaku perekonomian manusia menjadi banking minded dan mengubah nilai-nilai dan aspek-aspek bisnis itu sendiri, baik secara yuridis maupun secara sosiologis. Perkembangan bisnis dengan corak dan sistem apapun tidak bisa terlepas dari lembaga keuangan yang namanya bank. Deregulasi perbankan yang dilakukan oleh pemerintah selama ini justru untuk mendukung perekonomian agar berkembang lebih baik. Dengan diberlakukannya Undang-Undang Nomor 10 Tahun 1998 tentang perubahan atas Undang-Undang nomor 7 Tahun 1992 tentang Perbankan, merupakan kesempatan dan memberikan peluang bagi umat islam untuk mendirikan bank berdasarkan syariat islam, sebagai pendukung terhadap dunia bisnis dan perekonomian umat. Dengan kehadiran bank-bank yang berdasarkan syariat islam diharapkan dapat mempercepat kebangkitan perekonomian umat dalam memasuki era globalisasi.
\end{abstract}


Kata Kunci: Arbitrase Islam, Perspektif Islam, Hukum Positif

\section{A. Pendahuluan}

Di Indonesia mendirikan bank berdarakan syariat Islam dapat dikatakan sengat lamabat dibangdingkan dengan negara-negara lain. Sekalipun negara Indoneia bukan negara Islam, melainkan karean duduknya mayoritas muslim, merupakan suatu keawajaean apabila sebagian besar masyrakat menginginkan pendirian bank yang bercorak Islami, yaitu dengan prinsip syariah sebagai alternaitif bank tanpa bunga. Berkenaan dengan itu, Undang-Undang Nomor 10 Tahun 1998 telah mengakomodasi kepentingan umat Islam Indonesia. Sekalipun Bank Islam di dalam undang-undang itu tidak dikatakan suatu jenis bank yang berdiri sendiri di sapmping Bank Umum dab Bank Perkreditan Rakyat tetapi suatu Bank Umum dan Bank Perkreditan Rakyat boleh melakukan usahanya tidak berdarakan bunga, tetapi berdarakan prinsip syariah. ${ }^{1}$

Munculnya bank Islam di Indoneisa merupakan fenomena yang menarik dan juga merupakan titik kulminasi dalam upaya panjang beberpaa kalangan secara individual atau institusioanl telah terlibat dalam proses yang berkenaan dengan transformasi sosial masyarakat mereka. Bank-bank (pedesaan) Islam pertama di Indonesia, yakni Bank Perkreditan Rakyat Daerah Mardhatillah (BPRDM) dan Bank Perkreditan Rakyat Berkah Amal Sejahtera (BPRBAS) yang beroperasi berdasarkan Hukum Islam (syariah), didirikan pada 15 Juli 1991 di Bandung, Jawa Barat. ${ }^{2}$

Menurut Rudi Tri Santoso bahwa kredit perbankan bagaimanapun juga tetap mengandung risiko keuangan maupun risiko lainnya. Untuk itu demi terlaksananya sebuah prudential banking diperlukan prinsip kehatihatian dan asas konservatif dalam pemilihan line bisnis maupun para nasabahnya. ${ }^{3}$

Terjadinya kredit macet, kredit yang diragukan dan kredit kurang lancar pada debitur, dapat dikatakan sebagai timbulnya hubungan hukum antara pihak bank dengan debitur atau mungkin saja antara debitur dengan debitur lainnya. Dengan demikian, akan muncul problematika hukum di masyarakat. Apabila masalah ini diselesaikan di Pengadilan Negeri, akan menemui kesulitan karena Pengadilan Negeri tidak mengadili kasus yang berdasarkan Hukum Islam. Apabila sengketa bisnis itu diselesaikan di luar pengadilan, yaitu melalui Badan Arbitrase, maka Badan Arbitrase mana yang berwenang atau yang salah satu pihak melakukan pelanggaaran atau

\footnotetext{
1 Sutan Remy Syahdeini, Perbandingan Islam dan Kedudukannya dalam Tata Hukum Perbangkan Idnosesia, (Jakarta: PT Pustaka Utama Grafiti,Cet 1), hlm 19-20.

${ }^{2}$ Iwan Triyuno, Organisasi dan Akutansi Syariah, (Yogy akarta: Lkis, 2000), hlm. 99.

${ }^{3}$ Rudi Tri Santoso, Kredit Usaha Perbankan, (Yogy akarta: Andi, 1996), hlm. 12.
} 
wanprestasi, maka sanksi apa yang diberlakukan dari pihak bank kepada debiturnya atau sebaliknya dan juga antara debitur dengan debitur lainnya.

Proses penyelesaian sengketa membutuhkan waktu yang lama mengakibatkan perusahaan atau para pihak yang bersengketa mengalami ketidakpastian. Cara penyelesaian seperti itu tidak diterima dunia bisnis karena tidak sesuai dengan tuntutan zaman. Penyelesaian sengketa bisnis melalui lembaga peradilan tidak selalu menguntungkan secara adil bagi kepentingan para pihak yang bersengketa. ${ }^{4}$

Penyelesaian perkara melalui pengadilan terkadang hanya bersifat formalistik karena para pihak yang bersengketa dipaksakan untuk menerima keputusan pengadilan, walaupun putusan itu sendiri dianggap tidak memenuhi rasa keadilan. Selain itu, muncul belakang hari rasa dendam antara pihak sehingga sering bertindak main hakim sendiri melalui berbagai cara. Hal ini merupakan konsekuensi logis dari penyelesaian sengketa. ${ }^{5}$ Masalah itulah yang menjadi kekhawatiran masyrakat dan pemikir ekonomi Islam yang perlu mendapat perhatian bersama. Untuk mengantisipasi kekhawatiran tersebut, maka Majelis Ulama Indoneisa (MUI) telah memprakarsai dibentuknya Badan Arbitrase Muamalat Indonesia (BAMUI) yang diresmikan pada tanggal 21 Oktober 1993 di Jakarta.

Kemudian selama kurang lebih 10 (sepuluh) tahun Badan Arbitrase Muamalat Indonesia (BAMUI) menjalankan perannya, dan dengan pertimbangan yang ada bahwa anggota Pembina dan Pengurus Badan Arbitrase Muamalat Indonesia (BAMUI) sudah banyak yang meninggal dunia, juga bentuk badan hukum yayasan sebagaimana diatur dalam Undang-Undang Nomor 16 Tahun 2001 tentang Yayasan sudah tidak sesuai dengan kedudukan BAMUI tersebut, maka atas keputusan rapat Dewan Pimpinan Majelis Ulama Indonesia Nomor : Kep-09/MUI/XII/2003 tanggal 24 Desember 2003 nama Badan Arbitrase Muamalat Indonesia (BAMUI) diubah menjadi Badan Arbitrase Syariah Nasional (BASYARNAS) yang sebelumnya direkomendasikan dari hasil RAKERNAS MUI pada tanggal 23-26 Desember 2002. Badan Arbitrase Syariah Nasional (BASYARNAS).

Kehadiran Badan Arbitrase Syariah Nasional (BASYARNAS) sangat diharapkan oleh umat Islam Indonesia, bukan saja karena dilatarbelakangi oleh kesadaran dan kepentingan umat untuk melaksanakan syariat Islam, melainkan juga lebih dari itu adalah menjadi kebutuhan riil sejalan dengan perkembangan kehidupan ekonomi dan keuangan di kalangan umat. Karena itu, tujuan didirikan Badan Arbitrase Syariah Nasional (BASYARNAS) sebagai badan permanen dan independen yang berfungsi menyelesaikan

\footnotetext{
${ }^{4}$ Suyud Margono, ADR-Alternative Dispute Resolution dan Arbitrase Proses Pelembagaan dan Aspek Hukum, (Jakarta: Ghalia Indonesia, 2000), hlm. 12-13.

5 A. Rahmat Rosyadi dan Ngatino, Arbitrase dalam Prespektif Islam dan Hukum Positif, (Bandung: PT Citra Aditya Bakti, 2002), hlm. 9.
} 
kemungkinan terjadinya sengketa muamalat yang timbul dalam hubungan perdagangan, industri keuangan, jasa dan lain-lain di kalangan umat Islam.

Berdasarkan pemaparan di atas maka penulis tertarik mengaji bagaimana Sumber Hukum Islam Tentang Arbitrase Islam (Badan Arbitrase Syariah Nasional (BASYARNAS); dan bagaimana Kedudukan Badan Arbitrase Syariah Nasional (BASYARNAS) dalam Hukum Positif?

\section{B. Pembahasan}

\section{Sejarah Perkembangan BASYARNAS}

Arbitrase dapat disepadankan dengan istilah tahkim. Tahkim berasal dari kata hakkama, secara etimologis berarti menjadikan seseorang sebagai pencegah suatu sengketa.20 Lembaga ini telah dikenal sejak zaman praIslam. Pada masa itu, meskipun belum terdapat system peradilan yang terorganisir, setiap ada perselisihan mengenai hak milik waris dan hak-hak lainnya seringkali diselesaikan melalui bantuan juru damai atau wasit yang ditunjuk oleh masing-masing pihak yang berselisih. ${ }^{6}$

Gagasan berdirinya Lembaga Arbitrase Islam di Indonesia, diawali dengan bertemunya para pakar, cendekiawan muslim, praktisi hukum, para kyai dan ulama untuk bertukar pikiran tentang pentingnya lembaga arbitrase di Indonesia. Pertemuan ini dimotori Dewan Pimpinan Majelis Ulama Indonesia (MUI) pada tanggal 22 April 1992. Setelah mengadakan beberapa kali rapat dan beberapa kali penyempurnaan terhadap rancangan struktur organisasi dan prosedur beracara akhirnya pada tanggal 23 Oktober 1993 telah diresmikan Badan Arbitrase Muamalat Indonesia (BAMUI), ${ }^{7}$ sekarang telah berganti nama menjadi BASYARNAS yang diputuskan dalam Rakernas MUI tahun 2002. Perubahan bentuk dan pengurus BAMUI dituangkan dalam SK MUI No kep-09/MUI/XII/2003 tanggal 24 Desember 2003 sebagai lembaga arbiter yang menangani penyelesaian sengketa ekonomi syari'ah dibidang perbankan syari'ah dengan nasabahnya. Beberapa faktor yang melatarbelakangi berdirinya lembaga arbitrase berdasarkan syari'at Islam adalah semakin maraknya kesadaran dan keinginan umat terhadap pelaksanaan hukum Islam, disamping juga karena faktor pertumbuhan dan perkembangan lembaga-lembaga keuangan syari'ah yang semakin pesat di Indonesia, khususnya sejak berdirinya Bank Muamalat Indonesia tahun 1992. ${ }^{8}$

Pada akhirnya peresmian Badan arbitrase Muamalat Indonesia (BAMUI) dilangsungkan pada tanggal 21 oktober 1993. Nama yang

\footnotetext{
${ }^{6}$ A. Rahmat Rosy adi, Arbitrase Dalam Perspektif Islam dan Hukum Positif, hlm. 43.

7 Warkum Sumitro, Asas-asas Perbankan Islam dan Lembaga-lembaga Terkait (BAMUI, Takaful dan pasar Modal Syari'ah di Indonesia), hlm. 167.

${ }^{8}$ Ahmad Dimiy ati, Sejarah Lahirny a BAMUI dalam Arbitrase Islam di Indonesia, hlm. 191.
} 
diberikan pada saat diresmikan adalah BAMUI. Peresmiannya ditandai dengan penandatanganan akta notaris oleh dewan pendiri, yaitu Dewan Pimpinan Majelis Ulama (MUI) pusat yang diwakili K.H. Hasan Basri dan H.S. Projokusumo, masing-masing sebagai ketua umum dan sekretaris umum Dewan Pimpinan MUI. Sebagai saksi yang ikut menandatangani akta notaris masing-masing H.M. Soejono dan H. Zainulbahar Noor, S.E. (Dirut. Bank Muamalat Indonesia) saat itu.

Kemudian selama kurang lebih 10 tahun BAMUI menjalankan perannya dengan pertimbangan yang ada bahwa anggota pembina dan pengurus BAMUI sudah banyak yang meninggal dunia, juga bentuk badan hukum yayasan sebagaimana diatur dalam Undang-Undang Nomor 16 tahun 2001 tentang yayasan yang sudah tidak sesuai dengan kedudukan BAMUI tersebut. Dalam salinan akta notaris nomor 15 tanggal 29 Januari 2004 menyatakan bahwa keputusan rapat Dewan Pimpinan Majelis Ulama (MUI) Nomor : Kep 09/MUI/XII/2003 tanggal 24 Desember 2003 nama BAMUI diubah menjadi BASYARNAS yang sebelumnya direkomendasikan dari hasil RAKERNAS MUI pada tanggal 23-26 Desember 2002, sehingga nama BASYARNAS menjadi badan yang berada dibawah MUI dan merupakan perangkat organisasi MUI.

BASYARNAS berdiri secara otonom sebagai salah satu instrument hukum yang menyelesaikan perselisihan para pihak, baik yang datang dalam lingkungan bank Islam, asuransi Islam maupun pihak lain yang memerlukannya. Bahkan, dari kalangan nonmuslim pun dapat memanfaatkan BASYARNAS selama yang bersangkutan mempercayai kredibilitasnya dalam menyelesaikan sengketa.

Persoalan lain yang muncul antara yang pro dan kontra dengan adanya BASYARNAS juga menyangkut bentuk organisasinya, anggaran dasar, prosedur beracaranya dan lain-lain yang berkaitan dengan persidangan. Dengan memahami pandangan bahwa Arbitrase Islam diperlukan secara murni untuk kepentingan bisnis dan perekonomian umat, maka perbedaan pandangan tersebut dapat mempersatukan visi tentang perlu adanya BASYARNAS yang berdiri untuk menyelesaikan sengketa

\section{Sumber Hukum Islam tentang Arbitrase Islam (Badan Arbitrase Syariah Nasional (BASYARNAS)}

Keberadaan Badan Arbitrase Syariah Nasional (BASYARNAS) sebagai lembaga arbitrase Islam di Indonesia merupakan salah satu kaitan yuridis yang sangat menarik dalam prespektif Islam. Berdasarkan kajian yuridis, historis maupun sosiologis keislaman dapat dikemukakan bahwa sangat kuat landasan hukum yang bersumber dari AL-Qur'an dan As-Sunnah

\footnotetext{
${ }^{9}$ http://digilib.uinsby.ac.id/7920/5/bab2.pdf diakses tanggal 5 April 2016.
} 
serta Ijma'Ulama. Terdapat sejumlah alsan dan argumentasi tentang keharusan adanya Lemabaga Arbitrase Islam seperti halnya Badan Arbitrase Syariah Nasional (BASYARNAS). Demikian juga kenyataan sosiologis menunjukkan bahwa masyarakat dimanapun sangat membutuhkan suatu lembaga untuk menyelesaikan sengketa di antara mereka dengan cara mudah, murah, dan memperoleh rasa keadilan. ${ }^{10}$

Dari segi kajian yuridis formal keislaman, menunjukkan bahwa keharusan dan keberadaan Lembaga Arbitrase Islam (Badan Arbitrase Syariah Nasional (BASYARNAS) yang bertujuan menyelesaikan sengketa atau permasalahan umat Islam merupakan suatu kewajiban. Sumber hukum yang mengharuskan adanya Lembaga Arbitrase Islam (Badan Arbitrase Syariah Nasional (BASYARNAS), yaitu Al-Qur'an sebagai sumber hukum Islam pertama. Perintah Allah Swt. Tentang keharusan dan keberadaan Lembaga Arbitrase Islam terdapat dalam Al-Qur'an :

Surat Al-Hujarat:9 artinya:

"jika 2 (dua) golongan yang beriman bertengkar, damaikanlah mereka. Tetapi jika salah satu dari 2 (dua) golongan berlaku aniaya terhadap orang lain, maka perangilah orang yang menganiaya sampai kembali kepada perintah Allah Swt. Apabila ia telah kembali, damaikanlah keduanya dengan adil dan bertindaklah benar. Sesungguhnya Allah Swt sangat menyukai orang-orang yang berlaku adil."

Surat An-Nisa: 35 artinya:

"Dan jika kamu khawatir akan terjadi persengketaan antara keduanya (suami-istri), maka kirimlah seorang hakam (Arbiter) dari keluarga perempuan dan dari keluarga laki-laki. Jika kedua orang hakam itu mengadakan perbaikan (perdamaian) niscaya Allah Swt akan memberi taufik kepada suami-istri itu. Sesungguhnya Allah Swt Maha Mengetahui dan Mengenal.'

Dari kedua ayat tersebut dapat disimpulkan bahwa lembaga hakam dalam perspektif Hukum Islam atau Badan Arbitrase dalam perspektif Hukum Positif merupakan suatu kebutuhan untuk menyelesaikan sengketa umat/masyarakat di manapun berada Ukhuwah Islamiyah tetap terjaga secara utuh. Bahkan, pada Surat Al-Hujarat ayat 9 di atas disebutkan apabila salah satu dari keduanya melakukan wanprestasi atau pelanggaran (aniya), maka harus diberi sanksi dengan jalan upaya paksa (diperangi). Apalagi wanprestasi dan pelanggaran tersebut memunyai nilai eksekutorial, maka harus dilakukan upaya paksa tersebut sesuai dengan klausula perjanjian para pihak atau putusan Badan Arbitrase, baik putusan tunggal maupun majelis.

\footnotetext{
${ }^{10}$ Op Cit., A. Rahmat Rosy adi dan Ngatino, hlm. 104.
} 
Ajaran Islam memerintahkan bahwa memenuhi kewajiban sesuai dengan perjanjian atau yang dijanjikan merupakan kewajiban dan apabila mengabaikannya atau melakukan wanprestasi atau pelanggaran merupakan dosa yang harus dinal sanksi hukum. Dalam Al-Qur'an Surat Al-maidah ayat 1 yang artinya:

"Hai orang-orang yang beriman, hendaklah penuhilah perjanjianperjanjian"

Kata uqud dalam Al-Qur'an memunyai pengertian yang sangat komprehensif, mencangkup keseluruhan perjanjian. Seperti perjanjian dengan Allah Swt untuk menjalankan semua ibadah dan meninggalkan yang dilarang atau perjanjian di antara manusia. Jadi kata "uqud" dalam Hukum Islam memunyai lebih bayak konotasi dan lebih luas daripada "kontrak atau perjanjian" yang terdapat dalam hukum positif. ${ }^{11}$

Sember Hukum Islam kedua, yang mengharuskan adanya Lembaga Arbitrase Islam, yaitu As-Sunnah/al-Hadist. Bayak kejadian dan peristiwa yang dialami oleh Rasullah Saw sebagai Arbiter dalam menyelesaikan sengketa umat dan mendamaikan para pihak yang berselisih. Rasullah Saw yang memunyai gelar Al-Amin (orang terpercaya) dalam setiap terjadi perselisihan umat selalu tampil sebagai Arbiter Tunggal melalui proses dan sistem Arbitrase Ad-hoc yang sesuai dengan masa itu. Ketika Islam itu terus berkembang dan juga masalah umat Islam juga semakin luas, dengan sendirinya muncul berbagai sengketa, tidak hanya yang berkaitan dengan masalah-masalah perdata saja seperti konflik ekonomi dari keluarga. Tetapi juga merambah kepada masalah politik dan perang. Sebelum lembaga peradilan berkembang, hampir semua masalah ini diselesaikan melalui proses Arbitrase, baik Tunggal maupun Majelis oleh Rasullah Saw dan/atau para sahabatnya.

Di antara para perawi hadist, yaitu At-Tirmizi, Ibnu Majah, Al-Hakim dan Ibnu-Hibbah, telah meriwayatkan bahwa: ${ }^{12}$

"Rasullah Sawtelah bersabda, perjanjian di antara orang-orang muslim itu boleh, kecuali perjanjian menghalalkan yang haram dari mengharamkan yang halal. At-Tarmizi dalam hal ini menambahkan mumalah orang-orang muslim itu berdasarkan syarat-syarat mereka"

Bukhari dan Muslim meriwayatkan dai Abu Hurairah, bahwa $:^{13}$

"Rasullah Saw bersabda, ada seorang laki-laki membeli pekarangan dari seseorang. Orang yang membeli tanah pekarangan tersebut menemukan sebuah guci yang berisikan emas. Kata orang yang membeli pekarangan, ambillah esmasmu yang ada pada saya, aku hanya membeli daripadamu tanahnya dan

\footnotetext{
${ }^{11}$ A.Rahman I Doi, Muamalah, (Jakarta: PT Rajagrafindo Persada, 1996), hlm. 16.

${ }^{12}$ Sayid Sabiq, Fiqih Sunnah, Jilid 13, (Bandung: PT Al-Ma'arif1997), hlm 190.

${ }^{13}$ Fatur Rahman, Hadist-hadist tentang Peradilan Agama, Cet 1 (Jakarta: Bulan Bintang, 1977)
} 
tidak membeli emasnya. Jawab orang memiliki tanah, aku telah menjual kepadamu tanah dan barang-barang yang terdapat didalamnya. Kedua orang itu lalu bertahkim (mengankat arbiter) kepada seseorang. Kata orang yang diangkat menjadi Arbiter, apakah kaти berdua memunyai anak. Jawab dari salah seorang dari kedua yang bersengketa, ya saya memunyai seorang anak laki-laki, dan yang lain menjawab pula, saya memunyai anak perempuan. Kata Arbiter labih lanjut kawinkanlah anak laki-laki itu dengan anak perumpuan itu dan biayailah kedua mempelai dengan emas itu. Dan kedua orang tersebut menyedekahkan (sisanya kepada fakir miskin)"

Selain dasar hukum Arbitrase yang bersumber dari Al-Qur'an dan AsSunnah, juga bersumber dari Hukum Islam ketiga, yaitu Ikma (konsensus) para ulama dalam menetapkan hukum terhadap sesuatu yang dijadikan dasar hukum Islam. Dalam catatan sejarah Islam keberlakuan dan keberadaan lembaga tahkim (Arbitrase) pada masa sahabat banyak dilakukan dan mereka tidak menentangnya. Misalnya pernyataan Sayyididna Umar Ibnu Khatab, bahwa: ${ }^{14}$

"Tolaklah permusuhan hingga mereka berdamai, karena pemutusan perkara melalui pengadilan akan mengembangkan kedengkian di antara mereka"

Sebagai salah satu contoh dari keberhasilan Ijma Ulama itu adalah lahirnya Lembaga Arbitrase Islam Badan Arbitrase Syariah Nasional(BASYARNAS) atas dasar adanya kesepakatan para Ulama, Cendikiawan Muslim dan para ekonom Muslim di Indonesia yang digagas oleh Majelis Ulama Indonesia untuk mendirikan Lembaga Arbitrase Islam. Hal ini dipandang penting untuk mengantisipasi perkembangan kepentingan umat dalam berbagai kasus sengketa, terutama di bidang bisnis dan ekonomi.

Secara sossiologis keberadaan Lembaga Arbitrase Islam sangat diharapkan oleh masyarakat, dimanapun mereka hidup. Islam datang pada masyarakat yang sudah memunyai tetenan hukum, demi kelangsungan pergaulan hidup. Hukum Islam sebagai rahmatan lil'alamin yang antara lain mengoptimalkan hal yang positif dan mengikis habis adat yang merugikan kemudian digantikan dengan adat yang sesuai dengan martabat kemanusiaan. Pelembagaan adat dalam Hukum Islam diketahui antara lain dari sikap Rasullah Saw terhadap setiap yang sedang berlaku yang bisanya disebut sebagai Sunnah Taqririyah. ${ }^{15}$

Peristiwa lembaga tahkim (Arbitrase) secara eksplisit dinyatakan oleh Rasullah Saw malalui dialognya dengan Abu Syureih secara singkat dapat

\footnotetext{
${ }^{14}$ K.Suhrawardi lubis, Hukum Ekonomi Islam,(Jakarta: Sinar Grafika, 2000), hlm 179.

${ }^{15}$ Op Cit., A. Rahmat Rosy adi dan Ngatino, hlm 108.
} 
diungkapkan sebagai berikut: ${ }^{16}$ Abu Syureih berkata pada Nabi bahwa rakyatnya bila sedang terjadi persengketaan di antara mereka selalu mendatangi Abu Syurieh untuk bertahkim mencari penyelesaian secara sukarela di antara mereka dengan menyejukkan hati mereka hingga oleh kedua belah pihak dengan perasaan lega. Kemudian Rasullah Saw memberikan reaksi/ jawaban alangkah baiknya hal itu. Dengan kata lain, jawaban Rasullah Saw dapat diartikan sebagai persetujuan.

Alasan Rasullah dapat menerima tindakan Abu Syureih karena tahkim Arbitrase itu mengandung nilai-nilai positif dan konstruktif adalah sebagai berikut: $^{17}$

a. kedua pihak menyadari sepenuhnya perlunya penyelesaian yang terhormat dan bertanggung jawab;

b. secara sukarela mereka menyerahkan penyelesaian persengketaan itu kepada orang atau lembaga yang disetujui dan dipercayakannya;

c. secara sukarela mereka akan melaksanakan putusan arbiter sebagai konsekuensi atas kesempatan mereka mengangkat arbiter;

d. mereka menghargai hak orang lain, sekalipun orang lain itu adalah lawannya;

e. mereka tidak ingin merasa benar sendiri dan mengabaikan kebenaran yang mungkin ada pada orang lain;

f. mereka memiliki kesadaran hukum dan sekaligus kesadaran bernegara/bermasyarakat sehingga dapat dihindari tindakan main hakim sendiri; dan

g. sesungguhnya pelaksanaan tahkim/arbitrase itu didalamnya mengandung makna musyawarah dan perdamaian.

Dari uraian di atas dapat disimpulkan keberadaan Badan Arbitrase Syariah Nasional (BASYARNAS) sebagai salah satu contoh lembaga arbitrase Islam yang ada di Indonesia, apabila dilihat dari aspek yuridis memunyai dasar hukum yang sangat kuat, yaitu bersumber dari Al-Qur'an, As-Sunnah dan Ijma Ulama. Secara historis dapat dikatakan bahwa keberadaan lembaga Arbitrase Islam sudah sejak masa Rasulullah SAW dan berkembang sampai sekarang dari Lemabaga Ad-Hoc menjadi Lembaga Permanen. Demikian juga secara sosiologis keberadaan Arbitrase Islam merupakan kebutuhan umat dalam menyelesaikan setiap terjadi sengketa di antara mereka yang meliputi masalah politik, peperangan, perdagangan, keluarga, ekonomi dan bisnis. Selain juga dapat dilakukan secara murah, mudah dan cepat dibandingkan dengan proses pengadilan.

\section{Kedudukan Badan Arbitrase Syariah Nasional (BASYARNAS) dalam Hukum Positif}

\footnotetext{
${ }^{16}$ BAMUI, Arbitrase Islam di Indonesia, BAMUI/MAI, (Jakarta, 1994), hlm. 45.

${ }^{17} \mathrm{Ibid}$, hlm. 46.
} 
Menurut hartono Mardjono, bahwa adanya suatu "lembaga permanen" yang berfungsi untuk mennyelesaikan kemungkinan terjadinya sengketa perkara perdata di antara bank-bank syariat dengan para nasabahnya, atau khususnya menggunakan jasa mereka dan umumnya antara sesama umat Islam yang melakukan hubungan-hubungan keperdataan yang menjadi syariat sebagai dasarnya. adalah suatu kebutuhan yang sungguh-sungguh nyata. Selanjutnya, ia mengatakan bahwa kehadiran lembaga permanen yang berfungsi untuk menyelesaikan kemungkinan terjadinya sengketa perdata di antara pihak-pihak yang bersangkutan, di samping memang merupakan suatu kebutuhan nyata, juga memiliki dasar-dasar yang kuat berdasarkan hukum positif yang berlaku. ${ }^{18}$

Di dalam Mukadimah Yayasan Badan Arbitrase Muamlat Indonesia $\left(\right.$ BASYARNAS) ${ }^{19}$ dikemukakan bahwa Badan ini akan bekerja dalam kerangka peraturan resmi negara yang ada dan didasarkan pada kesadaran dan penghayatan hukum pelaku-pelaku muamalat itu, semuanya dilandasi oleh asas musyawarah mufakat dan akhlak Islam dalam kerangka Negara Ketentuan Republik Indonesia berdasarkan Pancasila dan Undang-Undang Dasar 1945.

Dari segi kelembagaan, status hukum Badan Arbitrase Syariah Nasional (BASYARNAS) adalah yayasan dibentuk berdasarkan Akta Notaris nommor 175 pada hari kamis tanggal 21 Oktober 1993 bertepatan dengan tanggal 5 Jumadil Awal 1414 Hijriyah. $^{20}$ Yayasan adalah badan hukum yang menjadi subyek hukum. Bahwa istilah yayasan pada mulanya digunakan sebagai terjemahan dari "stichting" dalam bahasa Belanda, "foundation" dalam bahasa inggris. Terdapat sejumlah definisi yayasan dikemukakan oleh para ahli, antara lain:

Dr.Chatamarrasyid, SH.,M mengemukakan bahwa: ${ }^{21}$

"Yayasan adalah suatu badan yang menjalankan usaha yang bergerak dalam segala macam usaha, baik yang bergerak dalam usaha yang nonkomersial maupun yang secara tidak langsung bersifat $100 \%$ komersial"

Paul Scholten mengemukakan bahwa: ${ }^{22}$

"Yayasan adalah suatu badan hukum yang dilahirkan oleh suatu pernyataan sepihak, pernyataan itu harus berisikan pemisahan

${ }^{18}$ H. Hartono Mardjono, Menegakan Syariat Islam dalam Konteks KeIndonesian, Mizan, Bandung, 1997, hlm 66.

${ }^{19}$ Op Cit., Badan Arbitrase Muamalat Indonesia, hlm. 15.

${ }^{20}$ Ibid.

${ }^{21}$ Chatamarrasyid, Tujuan Sosial Yayasan dan Kegiatan Usaha Bertujuan Laba, (Bandung: PT Citra Aditya Bakti, 2000), hlm. 5.

22 Ali Rido, Badan Hukum dan Kedudukan Badan Hukum Perseroaan, Perkumpulan, Koperasi, Yayasan, Wakaf, (Bandung: Alumni, 1986), hlm 22. 
suatu kekayaan untuk tujuan tertentu, dengan penunjukan bagaimana kenyataan itu harus diurus dan dipergunakan."

Berdasarkan definisi di atas Badan Arbitrase Syariah Nasional (BASYARNAS) sebagai yayasan/badan/lembaga Arbitrase Islam memunyai asas, tujuan, operasional, dan kewenangan yang tercantum di dalam Akta Pendirian, Anggaran Rumah Tangga dan Peraturan Prosedur Badan Arbitrase Syariah Nasional (BASYARNAS) dalam upaya hukum untuk menyelesaikan sengketa bisnis para pihak memunyai kewenangan tercantum dalam peraturan prosedur Badan Arbitrase Syariah Nasional (BASYARNAS) sebagi berikut: ${ }^{23}$

a. penyelesaian sengketa yang timbul dalam hubungan perdagangan industri, keungan jas dan lain-lain mana para pihak sepakat secdra tertulis untuk menyelesaikan penyelesaiannya kepada Badan Arbitrase Syariah Nasional (BASYARNAS) sesuai dengan Peraturan Prosedur Badan Arbitrase Syariah Nasional (BASYARNAS); dan

b. memberikan suatu pendapat yang mengikat tanpa adanya suatu sengketa mengenai suatu persoalan berkenaan dengan perjanjian atas permintaan para pihak. Kesepakatan klausula seperti itu bisa dicantumkan dalam perjanjian atau dalam suatu akta tersendiri setelah sengketa timbul.

Dari segi Tata Hukum Indonesia, keberadaan Badan Arbitrase Syariah Nasional (BASYARNAS) secara yuridis formal memunyai legitemasi yang kuat di negara Indonesia. Terdapat dasar hukum negara sebagai hukum positif yang berlaku saat ini memungkinkan suatu lembaga lain di luar lembaga peradilan umum dapat menjadi wasit/hakim dalam penyelesaian sengketa para pihak. Walaupun, penyelenggaraan kekuasaan kehakiman pada dasarnya diserahkan kepada badan peradilan dengan berpedoman kepada Undang-Undang Nomor 14 Tahun 1970 tentang Ketentuan-ketentuan Pokok Kehakiman. Hal tersebut merupakan induk dan kerangka umum yang meletakkan dasar dan asas peradilan serta pedoman bagi lingkungan Peradilan Umum, Peradilan Agama, Peradilan Militer dan Peradilan Tata Usaha Negara yang masing-masing diatur dalam undang-undang tersendiri. ${ }^{24}$

Namun demikian, di dalam penjelasan Pasal 3 ayat (1) UndangUndang Nomor 14 Tahun 1970 disebutkan antara lain, bahwa:

"Penyelesaian perkara di luar pengadilan atas dasar perdamaian atau melalui Arbitrase tetap diperbolehkan, akan tetapi putusan Arbiter hanya memunyai kekuatan eksekutorial setelah memperoleh izin atau perintah untuk eksekusi (executoir) dari pengadilan"

Selama ini yang dipakai sebagai dasar pemeriksaan Arbitrse di Indonesia adalah Pasal 615 sampai dengan 651 Reglemen Acara Perdata (Reglement op De Rechtvordering Staatsblad 1847) dan Pasal 377 Reglemen Indonesia yang diperbaharui (het Herziene Indonesisch Reglement, Staatbald

\footnotetext{
${ }^{23}$ Op Cit., Badan Arbitrase Muamalat Indonesia, hlm 30.

${ }^{24}$ Op Cit., A. Rahmat Rosy adi dan Ngatino, hlm. 112.
} 
1941) dan Pasal 705 Reglemen Acafra untuk Daerah Luar Jawa dan Madura (Rechtsreglement Buiitengewesten Staatblad 1927). Dengan diberlakukannya Undang-Undang Nomor 30 Tahun 1999 tentang Arbitrase dan Alternatif Penyelesaian Sengketa melalui Pasal 81 undang-undang tersebut secara tegas mencabut ketiga macam ketentuan tersebut terhitung sejak tanggal diundangkan. Maka berarti segala ketentuan yang berhubungan dengan Arbitrase, termasuk putusan Arbitrase asing tunduk pada ketentuan Undang-Undang Nomor 30 Tahun 1999, meskipun secara lex specialis ketentuan yang berhubungan (pelaksanaan) Arbitrase asing telah diatur dalam Undang-Undnag nomor 5 Tahun 1968 yang merupakan pengesahan atas persetujuan atas Konvensi tentang Penyelesaian Perselisihan AntarNegara dan Warga Negara Asing mengenai penanaman modal (International Centre for the Settlement of Invensment Disputes (ICSID) Convnebtion), Keputusan Presiden Nomor 34 Tahun 1981 tentang Pengesahaan New York Convention 1958 dan Peraturan Makamah Agung Nomor 1 Tahun 1990. ${ }^{25}$

Jadi kedudukan hukum Badan Arbitrase Syariah Nasional (BASYARNAS) dalam tata hukum Indonesia memunyai landasan hukum yang sangat kuat. Badan Arbitrase Muamalat Indonesia (BASYARNAS) sebagai lembaga Arbitrase Islam dengan status badan hukum Yayasan diberi atau memunyai kewenangan dalam upaya penyelesaian sengketa bisnis para pihak sesuai dengan Peraturan Prosedur Badan Arbitrase Syariah Nasional (BASYARNAS). Berdasarkan hukum positif yang berlaku yaitu UndangUndang Nomor 14 Tahun 1970 tentang Ketentuan-ketentuan Pokok Kekuasaan Kehakiman, pada Pasal 3 ayat (1) penyelesaian sengketa di luar pengadilan dibolehkan melalui lembaga Arbitrase. Hal demikian juga diatur melalui Undang-Undang Nomor 30 Tahun 1999 tentang Arbitrase dan Alternatif Penyelesaian Sengketa.

\section{Penutup}

1. Keberadaan Badan Arbitrase Syariah Nasional (BASYARNAS) sebagai salah satu contoh lembaga arbitrase Islam yang ada di Indonesia, apabila dilihat dari aspek yuridis, memunyai dasar hukum yang sangat kuat, baik dasar hukum negara maupun hukum Islam. Sumber hukum Islam mengenai Arbitrase diatur dalam Al-Qur'an, AS- Sunnah dan Ijma'Ulama. Secara historis dapat dikatakan bahwa keberadaan Lembaga Arbitrase Islam sudah sejak masa Rasulullah Saw dan berkembang sampai sekarang dari Lembaga Ad-Hoc menjadi Lembaga Permanen. Demikian juga secara sosiologis, keberadaan Arbitrase Islam merupakan kebutuhan umat dalam menyelesaikan setiap terjadi sengketa di antara mereka yang meliputi masalah politik, peperangan, perdagangan,

\footnotetext{
${ }^{25}$ Gunawan Widjaja dan Ahmad Yani, Hukum Arbitrase, (Jakarta: PT Raja Grafindo Persada, 2000), hlm. 5.
} 
keluarga, ekonomi dan bisnis. Selain itu, juga dapat dilakukan secara murah, mudah dan cepat dibandingkan dengan proses pengadilan.

2. Kedudukan Badan Arbitrase Syariah Nasional (BASYARNAS) dalam tata hukum Indonesia memunyai landasan hukum yang sangat kuat. Badan Arbitrase Muamalat (BASYARNAS) sebagai Lembaga Arbitrase dengan status badan hukum yayasan diberi atau memunyai kewenangan dalam upaya penyelesaian bisnis para pihak sesuai dengan Peraturan prosedur Badan Muamalat Indonesia (BASYARNAS). Berdasarkan hukum positifyang berlaku, yaitu Undang-Undang Nomor 14 Tahun 1970 tentang Ketentuan-Ketentuan Pokok Kekuasaan Kehakiman pada Pasal 3 ayat (1) penyelesaian sengketa di luar lembaga peradilan dibolehkan melalui lembaga Arbitrase. Hal demikian telah diatur melalui UndangUndang Nomor 30 Tahun 1999 tentang Arbitrase dan Alternatif Penyelesaian Sengketa.

\section{Daftar Pustaka}

BASYARNAS, 1994, Arbitrase Islam di Indonesia, Jakarta: BASYARNAS/MAI.

Chatamarrasyid, 2000, Tujuan Sosial Yayasan dan Kegiatan Usaha Bertujuan Laba, Bandung: PT Citra Aditya Bakti.

Doi, A.Rahman I, 1996, Muamalah, Jakarta: PT Rajagrafindo Persada.

Lubis, K. Suhrawardi, 2000, Hukum Ekonomi Islam, Jakarta: Sinar Grafika. Mardjono, H. Hartono, 1997, Menegakkan Syariat Islam dalam Konteks KeIndonesian, Bandung: Mizan.

Margono, Suyud, 2000, ADR-Alternative Dispute Resolution dan Arbitrase Proses Pelembagaan dan Aspek Hukum, Jakarta: Ghalia Indonesia.

Rahman, Fatur, Hadits-hadits tentang Peradilan Agama, Cet 1, Jakarta: Bulan Bintang.

Rido, Ali, 1986, Badan Hukum dan Kedudukan Badan Hukum Perseroaan, Perkumpulan, Koperasi, Yayasan, Wakaf, Bandung: Alumni.

Rosyadi, A. Rahmat dan Ngatino, 2002, Arbitrase dalam Prespektif Islam dan Hukum Positif, Bandung: PT Citra Aditya Bakti.

Sabiq Sayid, 1997, Fiqih Sunnah, Jilid 13, Bandung: PT Al-Ma'arif.

Santoso, Rudi Tri, 1996, Kredit Usaha Perbankan, Yogyakarta: Andi.

Sumitro, Warkum, Asas-Asas Perbankan Islam dan Lembaga-lembaga Terkait (BASYARNAS dan TAFAKUL) di Indonesia. PT Raja Grafinfo Persada, Jakarta, 1997.

Syahdeini, Sutan Remy, Perbandingan Islam dan Kedudukannya dalam Tata Hukum Perbankan Indonesia, PT Pustaka Utama Grafiti,Cet 1, Jakarta.

Triyuno, Iwan, Organisasi dan Akuntansi Syariah, Lkis, Yogyakarta, 2000. Widjaja, Gunawan dan Yani, Ahmad, Hukum Arbitrase, PT Raja Grafindo Persada, Jakarta, 2000. 